\title{
Calcium supplementation from dairy products in the diet of women over the age of 55 from Zabrze (the Silesian Osteoactive Study - nutritional part)
}

\author{
Katarzyna Martela ${ }^{1}$, Roman Kuźniewicz ${ }^{2}$, Wojciech Pluskiewicz ${ }^{2}$, Elżbieta Tabor ${ }^{3}$, Piotr Zagórski ${ }^{4}$ \\ ${ }^{1}$ Doctoral Studies, School of Medicine with the Division of Dentistry, Medical University of Silesia in Katowice, Zabrze, Poland \\ 2Department and Clinic of Internal Diseases, Diabetology, and Nephrology, School of Medicine with the Division of Dentistry, \\ Metabolic Bone Diseases Unit, Medical University of Silesia in Katowice, Zabrze, Poland \\ ${ }^{3}$ Department and Clinic of Internal Diseases, Diabetology, and Nephrology, School of Medicine with the Division of Dentistry, \\ Zabrze, Poland \\ ${ }^{4}$ Department of Orthopaedic Surgery, the Sports-Clinic, Żory, Poland
}

\begin{abstract}
Objectives: The primary goal of the study was to assess calcium intake among women over the age of 55 .

Material and methods: The study participants were randomly selected from the female population of Zabrze, a town in the Upper Silesia Region in Poland, making use of the framework of the Silesia Osteoactive Study Project. The Semi-Quantitative Food Frequency Questionnaire (sFFQ) was used for nutritional assessment. A total of 388 women at the median age of 65.2 years responded to written and mailed invitations and decided to participate in the study.

Results: The mean calcium intake in the group of enrolled post-menopausal women was 886.9 $\pm 615.1 \mathrm{mg} /$ day. Only $32.9 \%$ of the participants met the daily calcium intake criterion of $>1000$ g/day (the Estimated Average Requirement of 1000 mg according to the Nutrition Standards from 2017 for women in the age group of 51-65 years). Calcium supplementation, identified among women over the age of 55 years in Zabrze, was not sufficient and significantly differed from indicated nutrition standards. Fermented dairy products were the main source of calcium for the studied women. The quantity of calcium provided from yoghurts, kefirs and buttermilk was $338.3 \mathrm{mg} / \mathrm{day}$. The level of consumption of fortified plant products, e.g., soy milk, was found to be very low. Some of the study participants (approximately 32\%) reported the intake of calcium supplements or OTC medicinal products with calcium.

Conclusions: Summing up, the studied women reported low calcium intake levels, which calls for appropriate adjustments, including either dietary modifications or proper supplementation programmes with calcium containing agents.
\end{abstract}

Key words: diet, osteoporosis, calcium, supplementation, Food Frequency Questionnaire.

\section{Introduction}

According to the WHO's definition from 1993, osteoporosis is a systemic skeletal disease, characterised by low bone mass and microarchitectural bone deteriorations, associated with increased fragility [1].
Osteoporosis is one of the major medical and social problems in the population of elderly people for high fracture risks, leading even to death, with a significant reduction in the quality of life of affected patients. It should be emphasized that this medical condition may 
be classified among civilizational diseases, affecting more and more persons.

The epidemiological studies on the incidence of osteoporosis in Poland are far from sufficient. On the basis of the work carried out, it should be assumed that osteoporosis-related problems in women over the age of 50 may affect even $30 \%$ of this population. In 2010, 2.71 million osteoporotic fractures were recorded in Poland, out of which $80 \%$ concerned women. In turn, two osteoporotic fractures per minute are recorded in the world. According to worldwide epidemiological data, there were 9 million osteoporosis-related fractures during the year 2000, with a clearly growing trend since that time [2].

There are many factors which either predispose to or restrict the development of osteoporosis. They are associated with various pathomechanisms. Regarding post-menopausal women, the main bone mass density (BMD) reducing stimulus is the lower concentration of estrogens, i.e. the hormones which inhibit the bone resorption process [3]. Here, it should be emphasized that low bone density is the major factor increasing fracture risk. In addition, the results of many studies have demonstrated relationships of BMD with age, body mass and body composition in post-menopausal women [4].

Among environmental factors, nutrition provides a significant contribution to the development of osteoporosis. It is known that proper supplementation of calcium and vitamin $D_{3}$ in the diet plays a very important, prophylactic-therapeutic role [5]. Nevertheless, one should not forget about proper quantities of consumed magnesium, phosphorus, sodium, protein, vitamins $A$, $\mathrm{C}$, K or of essential unsaturated fatty acids [6]. Also there are many concerns over the negative impact which alcohol, coffee, tea [7] and other stimulants - plus cigarette smoking - exert on bone structure [8].

The goal of the reported study was to assess calcium intake with consumed dairy products, based on a validated short Food Frequency Questionnaire (sFFQ) [9].

\section{Material and methods}

\section{Material}

The study was carried out at the Department of Metabolic Diseases of the Medical University of Silesia
(SUM) in Zabrze, Poland, during the months of April and May 2015, with prior approval of the Bioethics Committee of the SUM No. KNW-2-031/D/5/N.

The study targeted women over the age of 55 years, living in Zabrze (Poland). All the respondents were randomly selected. The preliminary population included 3000 women and was disclosed by the Municipal Authority of Zabrze. The selected women were invited in written letters to take part in the study. Eventually, a group of 388 subjects agreed to participate. Prior to the final enrolment, all the women provided their conscious written consent to participate in the study. The mean age of the enrolled women was 65 years. Their mean body mass and body height were $74.1 \mathrm{~kg}$ and $157.9 \mathrm{~cm}$, respectively. The median BMI was $28.8 \mathrm{~kg} / \mathrm{m}^{2}$ (Table I).

\section{Methods}

The study subjects were to answer the questions contained in the short Food Frequency Questionnaire (sFFQ) [9]. The sFFQ document has been developed from the FFQ-6 questionnaire with questions concerning 165 food product groups, and used to obtain a cross-sectional evaluation of the nutrition status of the Polish population. After modification, only those questions which enquired about consumed components important for the bone system, primarily calcium, were left.

The questionnaire which was used in the study was based on the guidelines for nutritional epidemiological studies, also including FFQ (Food Frequency Questionnaire) employing projects [10]. The questions encompassed the frequency of consumption of milk, fermented dairy products (milk beverages), cheeses (including soft, processed, blue cheeses and cheese spreads), calcium fortified plant products or other products. The answers were divided into categories of foodstuff consumption frequency, i.e. in the following order: "never or almost never", "once a month or more rarely", "a few times during a month", "a few times a week", "every day", "a few times daily". In addition, the respondents were asked about portion sizes of the above-mentioned products. The provided answers enabled an estimation of calcium volumes, resulting from consumption of the products. The survey was carried out by an interviewing investigator. The answers were directly entered into

Table I. Descriptive characteristics of study group $(N=388)$

\begin{tabular}{|lccccccc|}
\hline Factor & Mean value & SD & Median value & Minimal value & Maximal value & Q25 & Q75 \\
\hline Age (years) & 65.2 & - & 65 & 55 & 87 & 60 & 70 \\
\hline Body mass $(\mathrm{kg})$ & 74.1 & - & 72.5 & 40 & 131 & 65.5 & 83 \\
\hline Body height $(\mathrm{cm})$ & 157.9 & 5.6 & - & 143.5 & 173.5 & 154 & 162 \\
\hline BMI $\left(\mathrm{kg} / \mathrm{m}^{2}\right)$ & 29.7 & - & 28.8 & 16.2 & 47.5 & 26.2 & 33.1 \\
\hline
\end{tabular}


Table II. Calcium supplementation in diet (from dairy and non-milk products)

\begin{tabular}{|lcccccc|}
\hline Factor & $\begin{array}{c}\text { Mean } \\
\text { value }\end{array}$ & SD & $\begin{array}{c}\text { Median } \\
\text { value }\end{array}$ & $\begin{array}{c}\text { Minimal } \\
\text { value }\end{array}$ & $\begin{array}{c}\text { Maximal } \\
\text { value }\end{array}$ & Q25-Q75 \\
\hline Mean supplementation of calcium per day $(\mathrm{mg})$ & 886.9 & 615.1 & 743.3 & 41.3 & 3886.3 & $510.7-1116.1$ \\
\hline Mean quantity of calcium from dairy products per day $(\mathrm{mg})$ & 745.7 & 599.0 & 615.8 & 0 & 3765 & $352.8-944$ \\
\hline Calcium supplementation from milk $(\mathrm{mg})$ & 273.6 & - & 171.3 & 0 & 3000 & $0-300$ \\
\hline Calcium supplementation from fermented dairy products $(\mathrm{mg})$ & 338.3 & - & 255 & 0 & 2550 & $76.5-436.8$ \\
\hline Calcium supplementation from cheeses $(\mathrm{mg})$ & 135.8 & - & 175.1 & 0 & 613.4 & $7.7-175.1$ \\
\hline $\begin{array}{l}\text { Calcium supplementation from fortified plant products } \\
\text { (e.g. soy products) (mg) }\end{array}$ & 8.4 & - & 0 & 0 & 246 & 0 \\
\hline
\end{tabular}

a calculation sheet by means of a computer-aided questionnaire (Google Forms).

The numerical values of calcium supplementation were obtained by multiplying the number and size of portions by the proportion coefficient, resulting from consumption frequency.

Calcium contents in the products were obtained from the table of nutritional qualities of selected products and of typical dishes [11]. These operations allowed for the conversion of the qualitative test into a semi-quantitative one. The calcium content in the diet of the studied women, obtained from calculation results, should be approached as approximate for the specificity of the sFFQ test. The reference values for that specific group at the given age were acquired from the Nutrition Standards for the Polish Population, IZZŻ 2017 [12]. The Estimated Average Requirement (EAR) value of 1000 mg/day was regarded as the reference value.

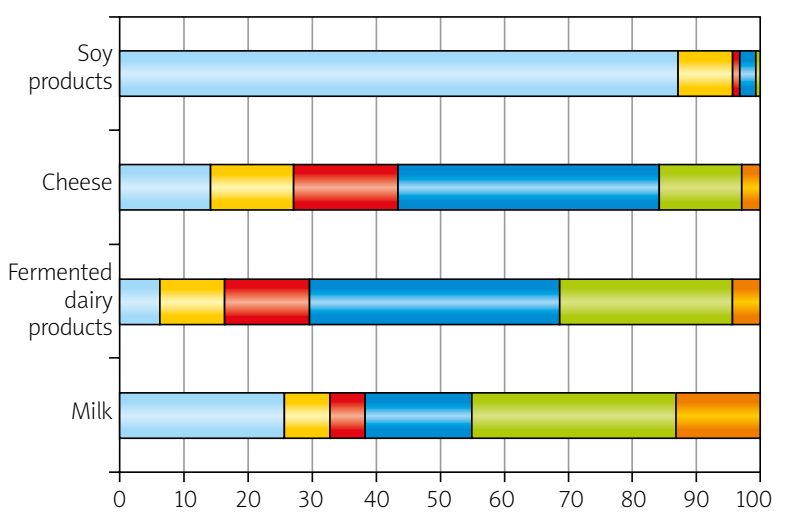

$\square$ never $\square$ 1-3 times per month $\square$ once a week $\square$ a few times a week $\square$ once a day $\square$ a few times during the day

Fig. 1. Cumulative graph of consumption frequency of milk, fermented dairy products, cheeses and soy products in the study group.
The obtained data were entered into a database, configured in the MS Excel 2010 program and then analysed by means of the Statistica 12.0 software package . The normality of distribution was verified using the Shapiro-Wilk test.

The descriptive statistics in Table I provide the mean and standard deviation values for the data which demonstrate normal distribution. For the data with non-normal distribution, their median values are presented. Regarding all data, their maximal and minimal values are specified, together with lower and upper quartiles.

\section{Results}

\section{Calcium content in the diet of studied female inhabitants of Zabrze}

The mean volume of calcium in the diet of studied subjects, quantified by means of sFFQ, was $886.9 \pm 615.1$ $\mathrm{mg} /$ day. Table II presents calcium quantities originating from particular dairy products and from the group of plant products - the asked questions concentrated mainly on soy products.

Performed calculations revealed that only 130 studied women (32.9\% of the entire study group) met the criteria of calcium intake at the required level of at least $1000 \mathrm{mg} /$ day.

\section{Frequency of milk and dairy product consumption}

As the collected data indicate, not all study participants confirmed the consumption of dairy products. Fifty-six women reported no consumption of either milk or dairy products in any form.

Milk and dairy products constituted a group of foodstuffs which provided more calcium than non-milk products. Fermented dairy products (beverages), such as yoghurts, kefirs or buttermilk, were the most common sources of calcium (Fig. 1). 
The mean volume of calcium from fortified plant products (i.e. from plant milks - soy, tofu) was $8.4 \mathrm{mg}$, which is a very low value when compared with the estimated average requirements (EAR) - the mean daily consumption assumed for the study group. In the presented analysis, the consumption of the element ranged from $41.3 \mathrm{mg}$ /day up to $3886.3 \mathrm{mg}$ /day.

The use of an additional medical-nutritional questionnaire indicated that a small number of the studied patients (124, i.e. $32 \%$ ) adhered to supplementation programmes with calcium-containing agents.

\section{Discussion}

\section{Calcium proportions in dairy and milk- free products - data from Polish nutrition studies}

Our results clearly demonstrate insufficient calcium intake in diets of the women participating in our study. Similarly as in the report of Bronkowska et al. [13], where the level of calcium intake corresponded to approximately $59.5 \%$ of the required standard, the diets of the respondents from Zabrze did not fully meet that demand, either. This fact seems to be particularly worrying. A similar volume of calcium supplementation is presented in the study of Skop-Lewandowska et al. [14], in which 66 elderly women were assessed with regards to nutritional risk factors of osteoporosis. The calcium content in their study group was approximately $500 \mathrm{mg}$ lower than that reported in our study.

The authors of many analyses indicate a trend of non-consumption of both milk and dairy products without medical indications [15]. The study of Włodarek et al. [16] showed the group of dairy products to be the main source of calcium, which is confirmed by our results. Fermented dairy drinks used to be the most frequently consumed dairy products. Similar results were obtained by Włodarek et al. in the RAC-POL-OST-STUDY [17].

\section{The use of fortified plant products in nutrition}

The development of nutritional technology and the expanded offer of available food products may suggest a higher level of consumption of other, calcium-rich foodstuffs, including fortified products. Unfortunately, our study confirmed neither calcium-rich fortified nor plant (e.g. soybean) products. It could result from elderly people being unconvinced about new, unknown foodstuffs. In addition, the prices of the offered beverages or processed products, such as tofu, significantly exceeded the prices of cows' milk and its products [18]. Therefore, these foods are rather often unavailable for the elderly population. Nevertheless, the inclusion of calcium forti- fied products in the diet may be a good and effective way to compensate calcium deficits.

\section{Other active nutrition components which may affect bone metabolism}

Soy-based products are an additional source not only of calcium but also of some other active components, e.g. of soy isoflavones. An extract from isoflavones $(60 \mathrm{mg})$, used in a randomized control study of women in post-menopausal age, could improve bone turnover rates [19]. The study of Manios et al. [20] confirmed that the use of a diet including fortified products brought about numerous benefits in comparison with persons on an unbalanced diet, complemented with calcium supplements.

\section{Effects of high phosphate diet on skeletal status}

It is worth adding that low calcium supplies are also observed in the populations of post-menopausal women in various countries all over the world [21]. Pinheiro in 2009 [22] reported a tendency towards insufficient calcium supply in the diet in parallel with excessive phosphorus supply, observed among studied Brazilian women over the age of 40 years. A high phosphate diet, with concurrent low calcium levels, may induce hormonal changes, leading to benign hyperparathyroidism.

A study performed by Lee et al. [23] on a group of 4935 Korean women highlighted the fact that not only the volumes of calcium and phosphorus mattered but their properly controlled ratio was important as well. The study demonstrated a positive correlation between the contents of calcium and phosphorus and the calcium to phosphorus ratio and BMD values in the cervical spines of the studied women. Despite the fact that phosphorus is a mineral which naturally occurs in cereals, meat and dairy products, a diet which restricts processed products and foodstuffs, preserved foods, e.g. tinned meat and fish, large quantities of sausages and smoked meat, as well as ready-made meals, is an important, phosphorus intake controlling factor. Such a diet will minimize the daily dose of phosphorus intake [24].

\section{Other nutrition products which affect the bone system status}

As confirmed by scientific research, proper calcium supplementation is a nutritional factor necessary for skeletal health [25]. A study of post-menopausal women in France revealed decreased calcium supplementation to below $800 \mathrm{mg} /$ day [26].

Following the applicable Nutrition Standards for the Polish Population from 2017, the quantity of calcium 
that should be consumed by women over the age of 55 years is $1200 \mathrm{mg} /$ day. The in-house research confirms that an insufficient calcium content in diet necessitates pharmacological supplementation, despite the fact that a balanced diet, introduced by modified nutrition habits, would be an optimal solution. It should also be emphasized that any analysis of nutrition with regards to its influence on the skeletal system status is neither simple nor unequivocal, due to, for example, the occurrence of many interactions which may both disturb and positively influence the bone structure status. Coffee and tea may be an example. Both substances, when excessively consumed, may lead to enhanced diuresis with accompanying urinary calcium excretion [27].

\section{Effects of a vegetarian diet on the risk of bone mass losses}

A fairly revealing aspect is the fact that a diet to be balanced with regards to the contents of calcium, vitamin $\mathrm{D}$, phosphorus or vitamin $\mathrm{K} 2$, need not require the presence of meat products. As noted in the study of Liu et al. [28], where the frequency of vegetable consumption was studied in the context of evaluation of, among other factors, bone parameters, the greater the volume of consumed vegetables was, the lower was the risk of osteoporosis development.

A subsequent study presented by Ho-Pham [29] addressed vegetarians and the effects of the vegetarian diet on bone mass losses. The results which the authors presented indicated that the vegetarian diet had no detrimental effects on bone mass, while the consumption of large quantities of meat protein and animal fats was responsible for a BMD drop. On the other hand, the analysis of Dardzinska et al. [30] indicates that persons on a vegetarian diet consume less calcium than subjects who remain on a traditional diet (including meat and its processed products). Such a situation may be associated with the selection of a vegetarian type. Persons on highly restrictive vegetarian and vegan diets are at especially high risk for deficiency of calcium, as well as of other, very important mineral components. Despite everything, vegetarians do not demonstrate any increased risk for osteoporosis or rapid bone mass loss [28]. Further investigation is therefore needed to increase our understanding of these mechanisms.

\section{Study limitations}

Any study within the scope of nutritional epidemiology is associated with methodological problems. In the case of our study, there was - among others - the issue of study duration; it had to be extended to increase the number of persons in the group. The response to the invitations to participate in the study was rather low (13\%), while the final group of enrolled participants appears to be satisfactory for epidemiological study. In addition, we had no opportunity to repeat the study, which would have provided a more complete nutrition picture of the studied subjects and could have enabled a more precise evaluation of the correlation between nutrition and bone structure status.

The SFFQ questionnaire used in the study consisted of a small (necessary) number of questions due to the limited willingness and possibilities of the patients to collaborate during the study. Nevertheless, the sFFQ tool enabled us to collect necessary information on the calcium-containing nutritional products, the data being adapted to the characteristic features of the diet of the Polish population.

Summing up, the female inhabitants of Zabrze represent a group of women with insufficient intake of calcium - a component which is necessary for bone health. Therefore, these persons are recommended to follow a balanced nutritional regimen and/or to adhere to a proper supplementation programme after doctor's consultation and dietary analysis.

\section{Conclusions}

Calcium supplementation, identified among women over the age of 55 years in Zabrze, was not sufficient and significantly differed from indicated nutrition standards.

The main calcium supplementing group of food products was fermented dairy products.

The dietary components of the studied female inhabitants of Zabrze demonstrated a very small proportion of calcium-fortified food categories.

In order to complement calcium supplementation, it is recommended either to adhere to a balanced diet or consider supplementation with calcium-containing agents in the situation when the actual diet includes inadequate calcium proportions.

The authors declare no conflict of interest.

\section{References}

1. http://www.4bonehealth.org/education/world-health-organization-criteria-diagnosis-osteoporosis/

2. The European Foundation of Osteoporosis and Musculoskeletal Diseases, The Polish Society of Orthopaedics and Traumatology, A Report - Osteoporosis - a silent epidemic in Poland. Kraków 2015.

3. Janiszewska M, Kulik T, Dziedzic M, et al. Osteoporoza, jako problem społeczny - patogeneza, objawy i czynniki ryzyka osteoporozy pomenopauzalnej. Probl Hig Epidemiol 2015; 96: 106-114. 
4. Marcinowska-Suchowierska E, Czerwiński E, Badurski J, et al. Osteoporoza - diagnostyka i terapia u osób starszych. Post Nauk Med 2011; 24: 410-423.

5. Dolińska B, Mikulska A, Ryszka F. Promotory wchłaniania wapnia. Ann Acad Med Siles 2009; 63: 76-83.

6. Philips F. Diet and bone health. Nutrition Bulletin 2004; 29 99-110.

7. Lorenc R, Głuszko P, Karczmarewicz E, et al. Zalecenia postępowania diagnostycznego i leczniczego w osteoporozie. Aktualizacja 2013. Med Prakt Reumatologia 2013; 1: 3-44.

8. Kopiczko A, Cieplińska J. Wpływ palenia papierosów na gęstość mineralną i masę tkanki kostnej u mężczyzn. MONZ 2014; 20: 449-452.

9. Jeżewska-Zychowicz M, Gawęcki J, Wądołowska L, et al. Kwestionariusz do badania poglądów i zwyczajów żywieniowych dla osób w wieku od 16 do 65 lat. A collective work edited by J. Gawęcki. Komitet Nauki o Żywieniu Człowieka Polskiej Akademii Nauk 2014; 3-15.

10. Wądołowska L. Walidacja kwestionariusza częstotliwości spożycia żywności FFQ. Ocena powtarzalności. Bromat Chem Toksykol 2005; 38: 27-33.

11. Kunachowicz H, Nadolna I, Iwanow K, et al. Wartość odżywcza wybranych produktów spożywczych i typowych potraw. Wyd. Lekarskie PZWL, Warszawa 2006.

12. Jarosz M (ed.). Normy żywienia dla populacji Polski. Instytut Żywności i Żywienia 2017. https://ncez.pl/abc-zywienia-/ zasady-zdrowego-zywienia/normy-zywienia-2017

13. Bronkowska M, Biernat J, Sadowska B. Podaż wybranych składników mineralnych $w$ racjach pokarmowych kobiet w okresie okołomenopauzalnym. Bromat Chem Toksyko 2009; 42: 24-29.

14. Skop-Lewandowska A, Ostachowska-Gąsior A, Kolarzyk E. Żywieniowe czynniki ryzyka osteoporozy u osób w podeszłym wieku. Gerontol Pol 2012; 20: 53-58.

15. Goluch-Koniuszy Z, Radziszewska M, Dega S. Ocena sposobu żywienia kobiet w okresie menopauzalnym - zdrowych i z leczoną osteoporozą. Agric Aliment Piscaria Zootech 2009; 269: 5-18.

16. Włodarek D, Sobocińska A, Głąbska D. Dairy calcium intake in diet of women aged over 60. Bromat Chem Toksykol 2012; 3: 833-838.

17.Włodarek D, Głąbska D, Kołota A, et al. Calcium intake and osteoporosis: the influence of calcium intake from dairy products on hip bone mineral density and fracture incidence - a population based study in women over 55 years of age. Public Health Nutr 2014; 17: 383-389.

18. Rybowska A. Produkty sojowe w opinii konsumentów Trójmiasta. Roczniki Naukowe Stowarzyszenia Ekonomistów Rolnictwa i Agrobiznesu 2016; 18: 310-314.
19. Lambert MNT, Thybo CB, Lykkeboe S, et al. Combined bioavailable isoflavones and probiotics improve bone status and estrogen metabolism in post-menopausal osteopenic women: a randomized controlled trial. Am J Clin Nutr 2017; 106: 909920.

20. Manios Y, Moschonis G, Panagiotakos DB, et al. Changes in biochemical indices of bone metabolism in post-menopausal women following a dietary intervention with fortified dairy products. J Hum Nutr Diet 2009; 22: 156-165.

21. Durosier-Izart C, Biver E, Merminod F, et al. Peripheral skeleton bone strength is positively correlated with total and dairy protein intakes in healthy postmenopausal women. Am J Clin Nutr 2017; 106: 513-525.

22. Pinheiro MM, Schuch NJ, Genaro PS, et al. Nutrient intakes related to osteoporotic fractures in men and women - The Brazilian Osteoporosis Study (BRAZOS). Nutr J 2009; 8: 6.

23. Lee KJ, Kim KS, Kim HN, et al. Association between dietary calcium and phosphorus intakes, dietary calcium/phosphorus ratio and bone mass in the Korean population. Nutr J 2014; 13: 114 .

24. Dardzińska J, Chabaj-Kędroń H, Małgorzewicz S. Osteoporoza jako choroba społeczna i cywilizacyjna - metody profilaktyki. Hygeia Public Health 2016; 51: 23-30.

25. Białokoz-Kalinowska I, Konstantynowicz J, Abramowicz P. Dieta w profilaktyce osteoporozy - zalecenia i kontrowersje. Pediatr Med Rodz 2013; 9: 350-356.

26. Fardellone P, Cotté FE, Roux C. Calcium intake and the risk of osteoporosis and fractures in French women. Joint Bone Spine 2010; 77: 154-158.

27. Hirata H, Kitamura K, Saito T, et al. Association between Dietary Intake and Bone Mineral Density in Japanese Postmenopausal Women: The Yokogoshi Cohort Study. Tohoku J Exp Med 2016; 239: 95-101.

28. Liu N, Zeng F, Zhang K, et al. A community-based cross-sectional study for relationship of frequency of vegetables intake and osteoporosis in a Chinese postmenopausal women sample. BMC Womens Health 2016; 3: 28.

29. Ho-Pham LT, Vu BQ, Lai TQ, et al. Vegetarianism, bone loss, fracture and vitamin D: a longitudinal study in Asian vegans and non-vegans. Eur J Clin Nutr 2012; 66: 75-82.

30. Dardzińska J, Banach D, Małgorzewicz S. Diety roślinne a ryzyko rozwoju osteoporozy. Forum Zaburzeń Metabolicznych 2016; 7: 99-105. 